\title{
Effects of mountain grassland maturity stage and grazing management on carotenoids in sward and cow's milk
}

\author{
Francisco CALDERÓN ${ }^{\mathrm{a}}$, Gabriele TORNAMBÉ ${ }^{\mathrm{b}}$, Bruno MARTIN ${ }^{\mathrm{a}}$, \\ Philippe PRADEL ${ }^{c}$, Béatrice ChaUveaU-Duriot ${ }^{\mathrm{a}}$, Pierre NozIÈrE ${ }^{\mathrm{a} *}$ \\ ${ }^{a}$ Unité de Recherche sur les Herbivores, INRA Theix, 63122 Saint-Genès-Champanelle, France \\ ${ }^{\mathrm{b}}$ Dipartimento S.En.Fi.Mi.Zo., Università degli Studi di Palermo, 90100 Palermo, Italia \\ ${ }^{\mathrm{c}}$ Domaine de la Borie, INRA Marcenat, 15330 Marcenat, France
}

(Received 8 November 2005 - Accepted 30 June 2006)

\begin{abstract}
Carotenoids are involved in the sensorial and nutritional values of dairy products. In grazing systems, both herbage maturity stage and grazing management may affect the amount of carotenoid ingested, thus these factors may affect carotenoid concentrations in milk. Two homogenous plots of mountain grassland (1.4 and $2.0 \mathrm{ha}$ ) were grazed during two cycles of growth by 6 dairy cows in mid lactation, in strip (SG) and rotational grazing (RG), respectively. We monitored the changes in carotenoid concentrations in sward and milk, measured by HPLC twice a week. Seven carotenoids were identified in the sward: violaxanthin, antheraxanthin, epilutein, lutein, zeaxanthin, $B$-carotene and 13-cis B-carotene. Forage quality decreased throughout the course of the first growth stage, but carotenoid concentration in sward did not significantly change. In early regrowth, forage quality was high and the concentration of $\beta$-carotene and xanthophylls also tended to be higher. Carotenoid concentrations in sward were not affected by grazing management, averaging $350 \mu \mathrm{g}$ per g DM. The carotenoids identified in milk were $\beta$-carotene $(75 \%)$ and lutein $(25 \%)$. A significant decrease in $\beta$-carotene concentration in milk was observed throughout the course of the first growth stage, from 5.37 to $3.87 \mu \mathrm{g}$ per g fat, whereas it increased to $4.91 \mu \mathrm{g}$ per g fat in early regrowth. $\beta$-carotene concentration in milk was not affected by grazing management, averaging 4.72 and $5.03 \mu \mathrm{g}$ per g fat for RG and SG, respectively. However, lutein concentration was slightly lower for RG than for SG, averaging 1.39 and $1.74 \mu \mathrm{g}$ per $\mathrm{g}$ fat, respectively. It is concluded that carotenoids in milk were only slightly affected by herbage maturity stage, and to a lesser extent by grazing management.
\end{abstract}

carotenoids / cow's milk / mountain grassland / maturity stage / grazing management

Résumé - Effets du stade de l'herbe et du mode de pâturage d'une prairie de montagne sur la teneur en caroténoïdes de l'herbe et du lait de vache. Les caroténoïdes sont impliqués dans les caractéristiques sensorielles et nutritionnelles des produits laitiers. Au pâturage, les teneurs en

*Corresponding author: noziere@clermont.inra.fr 
caroténoïdes du lait pourraient dépendre du stade de l'herbe et du mode de pâturage, qui conditionnent la quantité et la qualité de l'ingéré. Pour valider cette hypothèse, deux prairies naturelles de montagne homogènes, de 1,4 et 2,0 ha, ont été exploitées par 6 vaches en milieu de lactation, en pâturage tournant rapide (SG) et lent (RG), respectivement, pendant deux cycles de végétation. Nous avons suivi l'évolution des teneurs en caroténoides de l'herbe et du lait, déterminées par HPLC sur deux prélèvements par semaines. Dans l'herbe, sept caroténoïdes ont été identifiés : violaxanthine, anthéraxanthine, épilutéine, lutéine, zéaxanthine, $\beta$-carotène et 13 -cis $\beta$-carotène. Au cours du premier cycle de végétation, la valeur nutritive de l'herbe a fortement diminué, mais sa teneur en caroténoïdes n'a pas été significativement modifiée. Les teneurs en ß-carotène et xanthophylles et la valeur nutritive de l'herbe étaient les plus élevées au début du deuxième cycle. La concentration en caroténoïdes de l'herbe n'a pas été affectée par le mode de pâturage, et était en moyenne de $350 \mu \mathrm{g}$ par g MS. Dans le lait, les caroténoïdes identifiés ont été le $\beta$-carotène $(75 \%)$ et la lutéine $(25 \%)$. La concentration en $\beta$-carotène dans le lait a diminué significativement de 5,37 à 3,87 $\mu \mathrm{g}$ par g MG pendant le premier cycle de végétation, et était la plus élevée au début du deuxième cycle $(4,91 \mu \mathrm{g}$ par g MG). La concentration en ß-carotène dans le lait n'a pas été affectée par le mode de pâturage, en moyenne 4,72 et 5,03 $\mu \mathrm{g}$ par g MG pour RG et SG, respectivement. Cependant, la concentration en lutéine était légèrement plus faible avec $\mathrm{RG}(1,39 \mu \mathrm{g}$ par g MG) qu'avec $\mathrm{SG}(1,74 \mu \mathrm{g}$ par g MG). En conclusion, la concentration en caroténoïdes dans le lait a été légèrement affectée par le stade de l'herbe, et dans une moindre mesure par le mode de pâturage.

caroténö̈des / lait de vache / prairie de montagne / stade de l'herbe / mode de pâturage

\section{INTRODUCTION}

Carotenoids are natural pigment precursors of the yellow to red colour range in vegetal and animal tissues. They are synthesised by superior algae and plants, where they have specific functions related to photosynthesis. These compounds are characterised by a linear polyisoprene structure with conjugated double bonds, either not derived (lycopene, $\mathrm{C}_{40} \mathrm{H}_{56}$ ), or derived by cyclisation of the two extremities, with (xanthophylls) or without (carotenes) oxidation. Except in diets supplemented with synthetic B-carotene, forages represent the main source of carotenoids for ruminants, where they develop several functions including provitamin A function, antioxidant function, cell communication, enhancement of immune function, and UV skin and macula protection [25]. Nearly 10 carotenoids have been identified in forages: lutein, epilutein, antheraxanthin, zeaxanthin, neoxanthin and violaxanthin for xanthophylls, all-trans $B$-carotene, 13-cis $B$-carotene and $\alpha$-carotene for carotenes [3, 5, 13, 21]. Although xanthophylls, mainly lutein, ac- count for the main carotenoid in forages, $B$-carotene is the main carotenoid deposited in bovine tissues [27] and milk $[11,15]$. Many studies on $\beta$-carotene in bovines have been conducted to improve fertility [2] or reduce reproductive disorders [18] and mammary infections $[6,7]$. Furthermore, since the amount of $B$-carotene deposited in adipose tissue and/or secreted in milk fat varies widely according to the carotenoid content in the feed, it plays a role in the sensorial and nutritional value of the final carcass and dairy products [22]. Carotenoids are found in higher concentrations in milk produced through grass-based diets, especially pasture $[11,15]$. These characteristics are considered as positive or negative depending on the specific target market of the products [26]. Recently, there has been increasing consumer interest in a "clean and green image" of animal production, particularly grazing production systems. The value of dairy products can therefore be enhanced by the implementation of traceability systems. Along with other micronutrients (some fatty acids, fat-soluble vitamins, terpenes, flavonoids...), carotenoids have 
been recognised as potential feeding management biomarkers in dairy cows [16], but studies have mainly compared highly contrasting feeding situations $[11,15,20]$. In grazing systems, a change in carotenoids in milk in the course of time may depend on the change in both the amount of carotenoid intake and milk yield. The carotenoid concentration in sward may decrease as the plant maturity stage increases $[17,20]$. It has also been well established that in grazing systems, herbage maturity stage and grazing management influence the botanical composition, nutritive value and ingestibility of herbage, and subsequently the feeding choices of animals $[8,10]$. It was thus expected that maturity stage affects the amount of carotenoid ingested, particularly with low stocking rate situations of grazing management. However, since these factors may also affect milk yield, their impact on carotenoid concentrations in milk is unknown.

The aim of the present work was to study the influence of both herbage maturity stage and grazing management on carotenoid concentrations in sward and milk from dairy cows in mid-lactation.

\section{MATERIALS AND METHODS}

\subsection{Pastures, animals, and grazing management}

This experiment was conducted in a natural mountain grassland in the French Massif Central (1100 m a.s.1.), from the 31st of May to the 1st of July 2003 (first growth), then from the 1 st to the 6th of October 2003 (regrowth). The grassland was divided into two similar plots of 1.4 and 2.0 ha, each grazed by a group of six dairy cows in two ways: strip grazing (SG plot) or rotational grazing (RG plot) for compared two situations of availability and selectivity of forage. Under SG, fences were moved every two days, allowing a limited surface per animal of $75 \mathrm{~m}^{2}$ per cow per day. Under RG, during the first growth, 3 subplots of 0.67 ha each were defined and grazed over 3 successive periods: the cows were moved on the 13th and 24th of June, allowing surfaces of 93, 102 and $140 \mathrm{~m}^{2}$ per cow per day for the 3 periods, respectively. For the fourth experimental period (regrowth), the experiment was suspended after 6 days due to adverse climatic conditions, resulting in surfaces of 150 and $186 \mathrm{~m}^{2}$ per cow per day for SG and RG respectively.

Two homogeneous groups of multiparous dairy cows were formed according to breed (5 Tarentaise and 1 Montbeliarde per group), days in milk (96 days) and milk yield (22.6 kg per day) at the beginning of the experiment. Each group was allocated to either the SG or RG grazing management system.

A concentrate mixture (0.95 UFL, $110 \mathrm{~g}$ PDIN and 122 g PDIE per kg [12]; Galaxel production, UCL Centraliment, Aurillac, France) was fed individually after the morning milking. During the first 3 experimental periods (first growth), the amount of concentrate remained constant and was determined according to milk yield at the beginning of the experiment: $5.5 \mathrm{~kg}$ per day for cows producing more than $20 \mathrm{~kg}$ milk per day, $2.8 \mathrm{~kg}$ for cows producing 15 to $20 \mathrm{~kg}$ milk per day, and no concentrate for cows producing less than $15 \mathrm{~kg}$ milk per day. Between periods 3 and 4, the two groups of dairy cows grazed together, and the concentrate was given individually and adjusted weekly according to the cows' individual production. In addition to the concentrate, each animal received $180 \mathrm{~g}$ per $\mathrm{d}$ of a mineral supplement including $6 \times 10^{5}, 12 \times 10^{4}$ and $1300 \mathrm{UI}$ per $\mathrm{kg}$ of vitamins $\mathrm{A}, \mathrm{D} 3$ and $\mathrm{E}$, respectively. During the fourth period (regrowth), the animals were fed only grazed sward. 


\subsection{Milk and sward sampling}

Individual milk production was recorded twice daily, and milk fat was determined weekly on four consecutive milkings. Individual milk samples were collected on June $6,10,13$ (i.e. days 6,10 and 13 in period 1), June 17, 20 and 24 (i.e. days 3, 6 and 10 in period 2), June 27 and 30 (i.e. days 3 and 6 period 3), October 3 and 6 (i.e. days 3 and 6 period 4). Individual pooled samples of $50 \mathrm{~mL}(60 \%$ morning and $40 \%$ evening milk) were constituted, and then stored away from light at $-20{ }^{\circ} \mathrm{C}$ until determination of carotenoid concentrations.

Herbage samples were collected on the same days as milk. In each plot, five lines $(200 \mathrm{~cm} \times 10 \mathrm{~cm})$ were randomly collected by cutting at $2 \mathrm{~cm}$ above ground. One line was used to determine the botanical components, and three lines were dried at $103{ }^{\circ} \mathrm{C}$ for biomass determination, as described previously [24]. The remaining was stored in vacuum bags away from light at $-20{ }^{\circ} \mathrm{C}$ until determination of chemical composition, net energy for lactation, nitrogen and fill values (UFL, PDI and UEL, respectively [12]), according to Andrieu et al. [1], and carotenoid concentrations.

\subsection{Determination of carotenoid concentrations}

Carotenoid concentrations in sward and milk were determined by HPLC using the technique described by Lyan et al. [14] and modified according to Cardinault et al. [4] for forages and Nozière et al. [20] for milk. All extractions were performed at room temperature under yellow light, with echinenone as the internal standard. The HPLC apparatus consisted in a Waters Alliance 2996 HPLC with photodiode array detector monitoring between 280 and $600 \mathrm{~nm}$. Millenium 32 software (version 3.05.01) from Waters SA (Saint-Quentinen-Yvelines, France) was used for instru- ment control, data acquisition and data processing). Carotenoids were separated as described by Lyan et al. [14] using a $150 \times 4.6 \mathrm{~mm}, \mathrm{RP} \mathrm{C} 18,3 \mathrm{~mm} \mathrm{Nu}-$ cleosil column, coupled with a $250 \times$ $4.6 \mathrm{~mm}$ RP C18, $5 \mathrm{~mm}$ Vydac TPS4 column (Interchim, Mountluçon, France). The flow rate was $2 \mathrm{~mL}$ per min and the mobile phase consisted of acetonitrile $(70 \%)$, methanol-acetate ammonium $50 \mathrm{mM}(15 \%)$, dichloromethane (10\%) and water $(5 \%)$. Carotenoids were detected at $450 \mathrm{~nm}$ and identified by comparison of their retention time and spectral analysis with those of pure standard (>95\%). Concentrations of carotenoids were calculated by using an external standard curve and then were adjusted by percent recovery of the added internal standard.

\subsection{Statistical analysis}

Data were statistically analysed using the MIXED procedure of SAS [23]. Data on milk yield were analysed as repeated measurements with grazing management as the fixed effect. Sward and other milk data were analysed with grazing management, period, and day nested in period, with the grazing management $\times$ period interaction as the fixed effect. For all milk data, a covariate term using the data obtained from each cow on day 1 of the experiment was included in the model, and animal was included as a random effect. The within-period relationships between total carotenoids and chemical composition of sward were determined with a covariance model using the Minitab software [19].

\section{RESULTS}

\subsection{Sward}

The average herbage biomass available, the botanical composition and maturity 
Carotenoids in sward and cow's milk

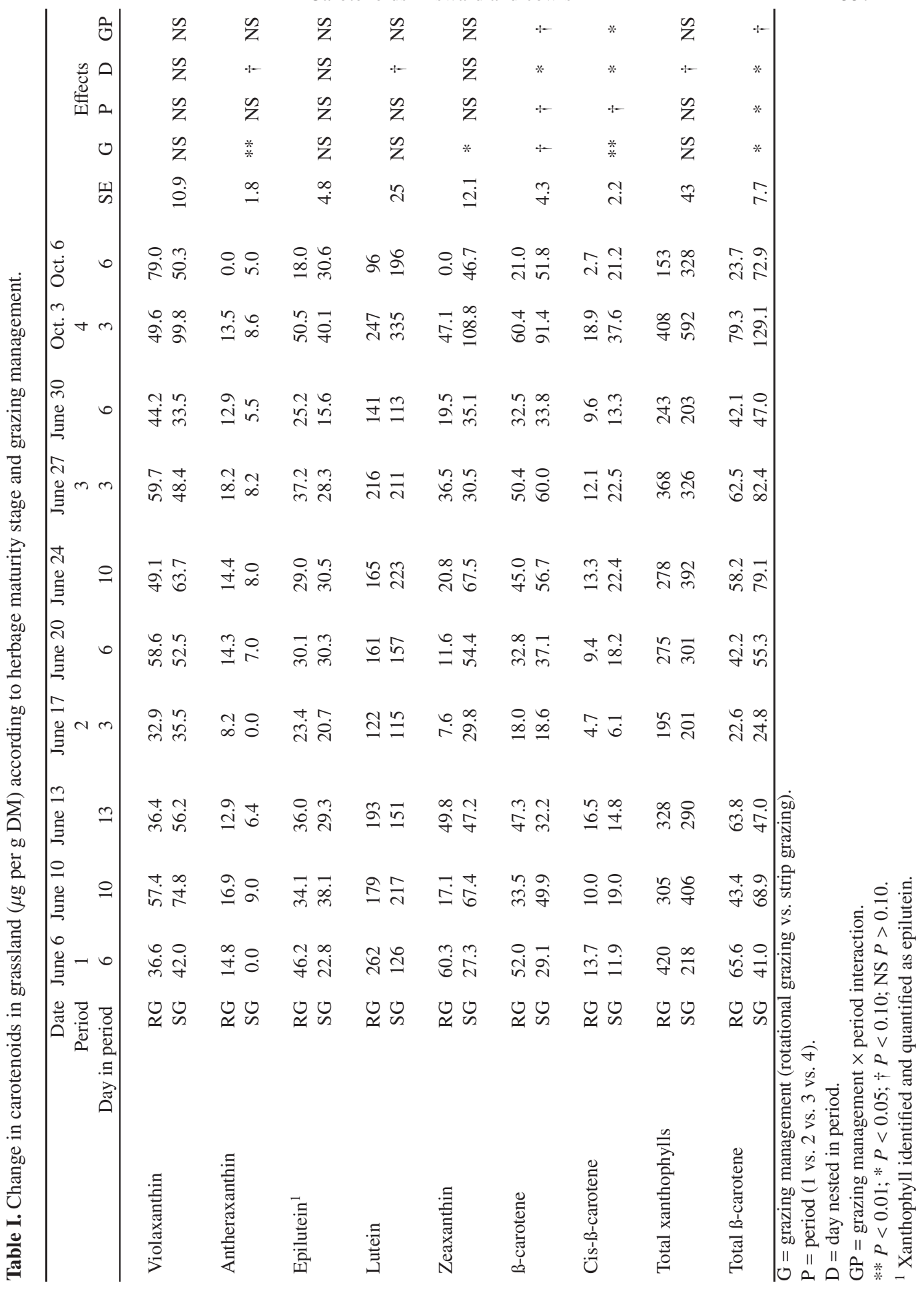


stage of the herbage have been reported previously [24]. Briefly, herbage biomass averaged $2.3,1.9,1.8$ and $0.8 \mathrm{~T} \mathrm{DM}$ per ha for the 4 experimental periods, respectively, corresponding to 17.3 vs. 21.4 , 14.3 vs. $19.4,13.5$ vs. 25.2 and 12.0 vs. $14.9 \mathrm{~kg}$ DM per cow per day for SG vs. RG, respectively. The grassland consisted in 14 poaceae and 32 dicotyledon species. The proportions of dicotyledons in DM weight of the pasture samples increased from $17 \%$ (period 1$)$ to $31 \%($ period 3$)$ and was $22 \%$ for period 4 . The maturity stage was noted once a week for 3 key plants. Between 1st June and 1st July, it changed from boot to ripening stage for Dactylis glomerata, from complete flowering to seed formation stage and leafy regrowth for Meum Athamanticum, and from leafy to $75 \%$ flower stage for Achillea millefollium.

In sward, seven carotenoids were identified (Tab. I): violaxanthin, antheraxanthin, lutein, zeaxanthin, all-trans $\beta$-carotene, 13cis B-carotene, and a xanthophyll identified and quantified as epilutein, averaging $14 \%$, $3 \%, 49 \%, 10 \%, 11 \%, 4 \%$ and $9 \%$ of total carotenoids. Concentrations of carotenoids in sward did not vary significantly over the first 3 periods, which corresponded to the first cycle of growth (Fig. 1). Concentrations of $B$-carotene tended to be higher at the beginning of the 4th period (regrowth), and the same trend was observed for xanthophylls, although failing to reach statistical significance. Concentrations of most carotenoids decreased strongly during this 4 th period. Concentrations of most carotenoids were not affected by grazing management, averaging 351 and $348 \mu \mathrm{g}$ total carotenoids per g DM for RG and $\mathrm{SG}$, respectively. However, antheraxanthin was slightly higher and zeaxanthin slightly lower in RG than in SG. In addition, alltrans and 13-cis B-carotene concentrations were lower in RG than in SG, but differences mainly occurred during the 4th period (regrowth).
Forage quality decreased over the first 3 periods, which corresponded to first growth (Fig. 1). Between 6th and 30th June, crude protein $(\mathrm{CP})$, organic matter digestibility (OMD), net energy and nitrogen values decreased from 139 to $104 \mathrm{~g}$ per $\mathrm{kg}$ DM $(P=0.044), 71$ to $63 \%(P=0.027)$, 0.90 to 0.76 UFL per $\mathrm{kg} \mathrm{DM}(P=0.023)$ and 87 to $66 \mathrm{~g}$ PDI per $\mathrm{kg} \mathrm{DM}(P=0.012)$, respectively, whereas fill value increased from 1.05 to 1.14 UEL per $\mathrm{kg} \mathrm{DM}(P=$ 0.028 ), and crude fibre (CF) content did not significantly vary (297 to 294 g per kg DM, $P=0.90)$. Forage quality was the highest $(P<0.01)$ during the 4 th period, corresponding to regrowth, where $\mathrm{CF}$ and $\mathrm{CP}$ content and $\mathrm{OMD}$, net energy, nitrogen and fill values averaged $250 \mathrm{~g}$ per $\mathrm{kg}$ DM, $171 \mathrm{~g}$ per kg DM, 75\%, 0.97 UFL per kg DM, $96 \mathrm{~g}$ PDI per kg DM and 0.99 UEL per kg $\mathrm{DM}$, respectively. The effect of day nested in period was not statistically significant on any of the variables tested, although forage quality tended to decrease during the 4th period. There were no significant differences in chemical composition or nutritive value of plots between grazing managements.

Significant correlations $(P<0.001)$ were observed between total carotenoids and CF, CP, and OMD (Fig. 2). Within experimental periods, the slopes of the relationships between total carotenoids and $\mathrm{CF}, \mathrm{CP}$ or OMD, were similar for both $\mathrm{SG}$ and RG $(P=0.36, P=0.15, P=0.23$, respectively).

\subsection{Milk}

All-trans $\beta$-carotene $(75 \%)$ and lutein $(25 \%)$ were the only carotenoids identified in milk (Fig. 3). In milk, there was a significant decrease $(P<0.0001)$ in both $B$ carotene yield (from 4.17 to $2.38 \mathrm{mg}$ per d) and concentrations ( 0.191 to $0.154 \mu \mathrm{g}$ per $\mathrm{mL}$, i.e. 5.38 to $4.25 \mu \mathrm{g}$ per $\mathrm{g}$ fat) during the first three periods. In the 4th period, 

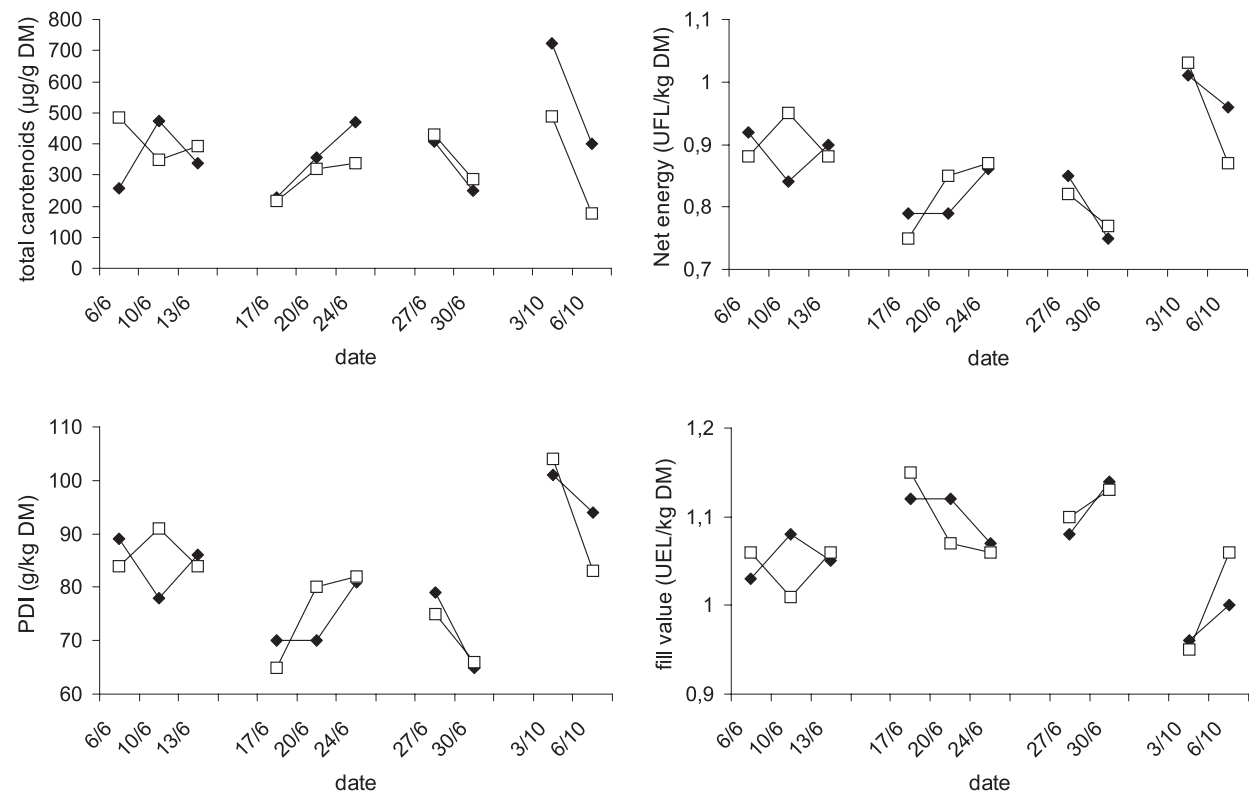

Figure 1. Change in total carotenoids, net energy, nitrogen and fill values of grassland according to herbage maturity stage and grazing management ( strip grazing; $\square$ rotational grazing).

the concentration of $\beta$-carotene in milk increased to $0.208 \mu \mathrm{g}$ per $\mathrm{mL}(P<0.0001)$, i.e. $4.93 \mu \mathrm{g}$ per $\mathrm{g}$ fat $(P<0.005)$. Between periods 3 and 4 , yield of $B$-carotene decreased under SG $(P=0.018)$ but did not significantly differ under RG $(P=0.76)$. In contrast with $B$-carotene, there was a slight increase in lutein in milk during the first three periods $(P<0.0001)$, from 0.052 to $0.066 \mu \mathrm{g}$ per $\mathrm{mL}$, i.e. 1.46 to $1.78 \mu \mathrm{g}$ per $\mathrm{g}$ fat, but lutein yield was not significantly affected $(P=0.99)$, averaging $0.98 \mathrm{mg}$ per d. Both yield $(P<0.0001)$ and concentrations of lutein $(P<0.001)$ significantly decreased between periods 3 and 4 under SG, but remained unaffected under RG $(P=0.09$ and $P=0.33$, respectively). There was no significant grazing management effect on concentrations of $\beta$-carotene in milk or $\beta$-carotene yield $(P=0.48)$. Concentrations averaged 0.178 and $0.185 \mu \mathrm{g}$ per $\mathrm{mL}(P=0.76)$, i.e. 4.72 and $5.03 \mu \mathrm{g}$ per $\mathrm{g}$ fat $(P=0.57)$ for $\mathrm{RG}$ and SG, respectively. However, concentrations of lutein in milk and lutein yield were slightly lower under RG compared to SG, i.e. 0.78 vs. $1.03 \mathrm{mg}$ per $\mathrm{d}(P=0.03)$ and 0.052 vs. $0.065 \mu \mathrm{g}$ per $\mathrm{mL}(P<0.001)$, i.e. 1.39 vs. $1.74 \mu \mathrm{g}$ per $\mathrm{g}$ fat $(P<0.0001)$, respectively. This difference occurred mainly during periods 2 and 3 .

Milk yield (data not shown) decreased drastically during the experiment $(P<$ 0.0001 ) from 22.4 to $9.3 \mathrm{~kg}$ per day on average between the beginning (96 days in milk) and the end (220 days in milk) of the experiment. This decrease was particularly pronounced during the 4th period, and was similar between the SG and RG groups $(P=0.93)$. Milk yield averaged 22.4 and 22.0 (period 1), 19.8 and 19.0 (period 2), 18.0 and 17.1 (period 3), 12.8 and 12.1 (period 4) kg per day for RG and SG, respectively. Milk fat (data not shown) did not significantly vary during the first three periods $(P=0.319)$, averaging $36 \mathrm{~g}$ per $\mathrm{kg}$, 

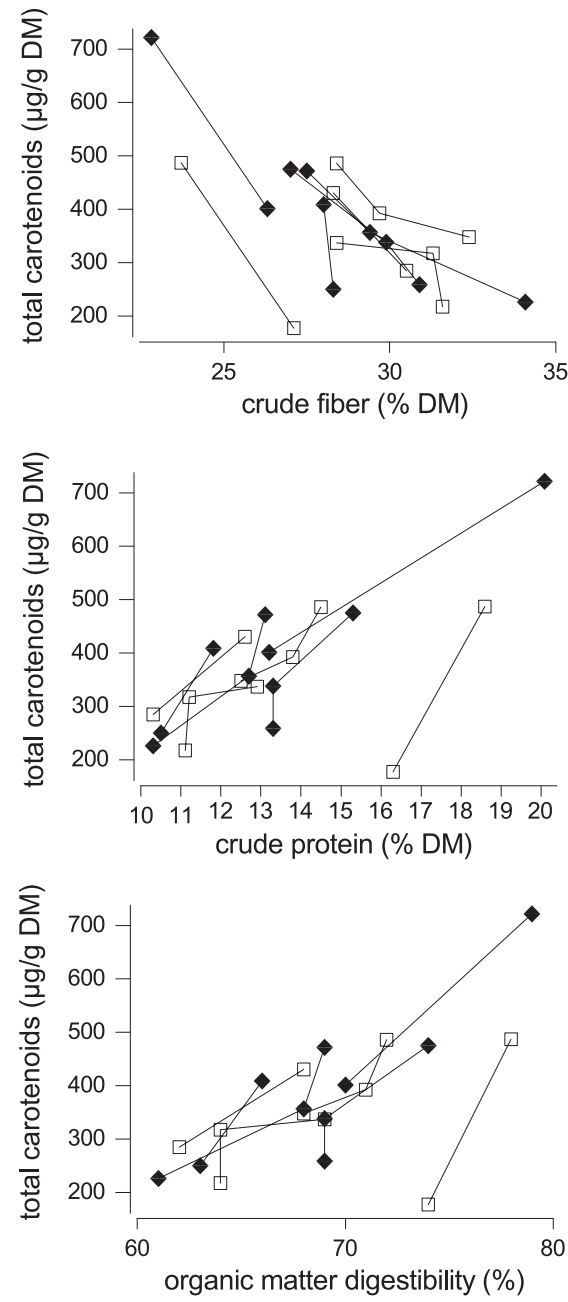

Figure 2. Within-period relationship between total carotenoids (TC, $\mu$ g per g DM) and crude fibre $(\mathrm{CF}, \% \mathrm{DM})$, crude protein $(\mathrm{CP}, \% \mathrm{DM})$, or organic matter digestibility (OMD, \%) of grassland, according to grazing management ( strip grazing; $\square$ rotational grazing). TC $=$ $1766( \pm 249)^{* * *}-48.9( \pm 8.7)^{* * *} \mathrm{CF}, \mathrm{N}=$ 20, Nper $=8$, RMSE $=68, \mathrm{R}^{2}=0.83$. TC $=$ $-455( \pm 126)^{* * *}+61.4( \pm 9.3)^{* * *} \mathrm{CP}, \mathrm{N}=$ 20 , Nper $=8$, RMSE $=60, \mathrm{R}^{2}=0.87$. TC $=$ $-1828( \pm 345)^{* * *}+31.9( \pm 5.0)^{* * *} \mathrm{OMD}, \mathrm{N}=$ 20 , Nper $=8$, RMSE $=61, \mathrm{R}^{2}=0.86 . * * *$ $P<0.001, \mathrm{~N}=$ number of data, $\mathrm{Nper}=$ number of period $\times$ grazing management, $\mathrm{RMSE}=$ root of mean square error. but increased significantly $(P<0.0001)$ to an average $42 \mathrm{~g}$ per $\mathrm{kg}$ in the 4 th period. Milk yield and milk fat content were not affected by the grazing management system, averaging 16.8 and $16.9 \mathrm{~kg}$ per day and 37.3 and $37.5 \mathrm{~g}$ per $\mathrm{kg}$ for RG and SG, respectively.

\section{DISCUSSION}

\subsection{Milk yield and forage quality}

The decrease in milk yield during the first three experimental periods, i.e. $-26 \%$ in one month, was remarkably high compared to what is commonly observed during this lactation period for multiparous animals with similar potential [9]. It is certainly related to the decrease in nutrient intake from forage, whereas we chose to provide a constant amount of concentrate throughout the first growth period. Both the strong decrease in nutritive value and the increase in fill value are likely to be responsible for a marked decrease in intake. The change in sward quality in this experiment was almost certainly related to particular climatic conditions during the summer of 2003. During this period, temperatures were high and precipitations were low compared to average values for the previous 35 years $\left(19.1\right.$ vs. $12.0{ }^{\circ} \mathrm{C}$, 43 vs. $96 \mathrm{~mm}$ ). These conditions hindered herbage growth, which in turn affected forage quality and led to a significant increase in DM compared to what is commonly observed in this area under normal climate conditions and in conditions where herbage availability is not limiting [12]. Furthermore, there were significant variations in the maturity stage of key plants during the first 3 periods, from vegetative to mature stage for Dactylis glomerata, flowering to reproductive stage and leafy regrowth for Meum athamanticum, and leafy to $75 \%$ flowers for Achillea millefollium from June 3rd to 1st July, as previously reported by Tornambé et al. [24]. The 

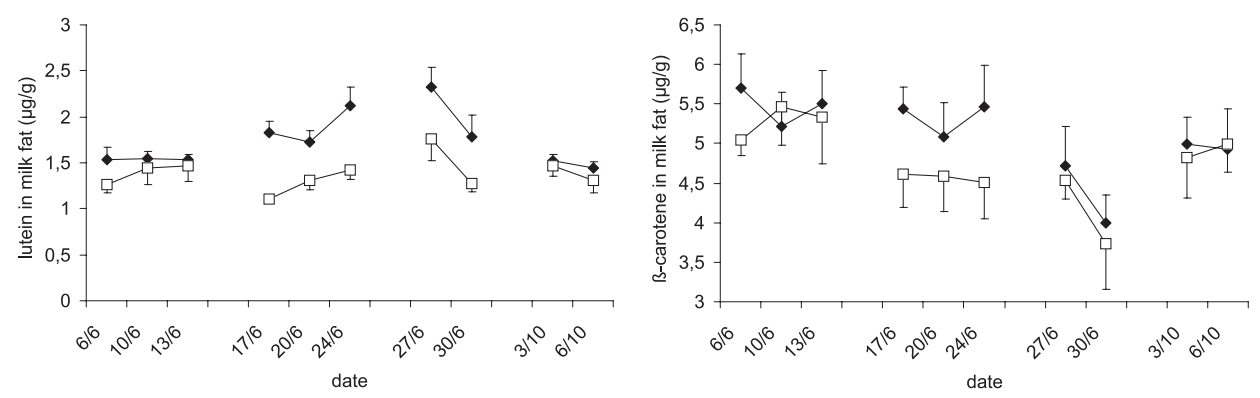

Figure 3. Change in lutein and $\beta$-carotene in milk fat according to herbage maturity stage and grazing management ( strip grazing; $\square$ rotational grazing); values are means for 6 cows \pm SEM).

decrease in milk yield was less marked between experimental periods 3 and $4(-22 \%$ in 2 months), due to more usual feeding management (higher amounts of concentrate) and higher nutritive value and digestibility of forage at the beginning of the 4th period, which corresponded to regrowth. The drastic decrease in milk yield during this 4th period was due to snow that began to fall, thus rapidly affecting ingestion. The experiment was thus stopped 6 days after the beginning of the 4th period.

No grazing management effect was observed on chemical composition or nutritive value of the plots, nor on milk production. This suggests that intake of digestible nutrients was similar in both groups, although average stocking rate was lower for $\mathrm{SG}$ than for RG, i.e. 75 vs. $113 \mathrm{~m}^{2}$ per cow per day during the first 3 periods (1st growth) and 150 vs. $186 \mathrm{~m}^{2}$ per cow per day during the 4th period (regrowth), respectively. However, this result does not preclude a potential effect of grazing management on the nature of the plant items the animals chose to ingest.

\subsection{Carotenoids in sward and milk}

Total carotenoid concentrations in the pasture averaged $350 \mu \mathrm{g}$ per g DM for the 1st growth period and $447 \mu \mathrm{g}$ per $\mathrm{g}$ $\mathrm{DM}$ for the regrowth period. This increase was consistent with the increase in nutri- tive value. Also, within each experimental period, it should be underlined that evolutions in carotenoid concentrations paralleled evolutions in the nutritive value of sward, irrespectively of grazing management, as illustrated by Figure 2. Carotenoid concentrations, averaging $350 \mu \mathrm{g}$ per $\mathrm{g}$ $\mathrm{DM}$, were $46 \%$ lower than those reported by Prache et al. [21] for pasture in less drastic climatic conditions, i.e. June 2002 at $800 \mathrm{~m}$ a.s.l. (averaging $650 \mu \mathrm{g}$ per $\mathrm{g}$ DM). Data on the diversity of xanthophylls and carotene in forages remain scarce $[4,5,21]$. In the present study, we detected 5 different xanthophylls and both 13 -cis and all-trans isomers of $\beta$-carotene. Epilutein corresponded to a xanthophyll identified and quantified according to retention time and HPLC spectrum of an epilutein standard, as previously reported in forage [3-5], digesta and plasma from sheep [3, 4]. However, further analyses are required to characterise this molecule more accurately. The change in carotenoid concentrations from the beginning to the end of the experiment remained comparable among molecules. This evolution was moderate throughout the first 3 periods, although both the vegetative stage of herbage (as described above) and the botanical compositions of the available herbage varied significantly: a proportion of dicotyledons increased from $17 \%$ to $31 \%$ of DM weight [24]. 
The main carotenoids recovered in milk were all-trans- $\beta$-carotene followed by lutein, which was consistent with what is generally reported. Zeaxanthin, which was present at a non-negligible level in pasture, was not recovered in milk, although its ability to be secreted in milk has been demonstrated [11]. Preliminary results indicate instability of violaxanthin and antheraxanthin in the rumen [3], which may be related to microbial degradation or conversion into zeaxanthin [25]. In contrast, intestinal absorption has been reported in sheep for epilutein and 13-cis B-carotene [4]. The presence of epilutein has previously been reported in plasma from sheep [4] but not in cows, whereas 13 -cis $\beta$-carotene has been evidenced in plasma from dairy cows [20] but not in sheep. It is important to note that the proportion of $\beta$-carotenes in total carotenoids in milk was lower in the present study (75\%) than in previously reported trials (85\%) $[11,15,17]$. This may be related to the low proportion of $\beta$-carotene in total carotenoids in sward in the present study (averaging 15\%), compared to other determinations on pasture (34-37\% [21]) or grass silage $(22-23 \%$, [5]). In the present study, concentrations of $\beta$-carotene and lutein in milk were comparable to those previously reported with similar breeds grazing in the same geographical area [15].

The moderate decrease in $B$-carotene concentrations in milk over the 3 first periods ( $21 \%$ on average) was consistent with the results reported by Martin et al. [15]. It may be attributed to the balance between a high decrease in intake of $\beta$-carotene and the high decrease in milk yield inducing a concentration effect. As discussed above, DM intake may have drastically decreased during the three first growth periods, inducing a large decrease in $B$-carotene intake, whereas $B$-carotene concentrations in sward were only slightly affected. At a constant $B$-carotene intake, a decrease in milk yield has been shown to increase milk concentrations of $\beta$-carotene [20]. Also, variations in $B$-carotene digestibility with herbage maturity cannot be excluded, but have not been demonstrated to date. Between periods 3 and 4 , the increase in milk concentrations of $\beta$-carotene was consistent with the increased forage digestibility and concentrations of B-carotene, together with the low decrease in milk yield. In contrast to $\beta$-carotene, milk concentrations of lutein increased through the 3 first growth periods, and only slightly varied between periods 3 and 4 . It is likely that compared to $\beta$-carotene, plasma concentrations of lutein are less sensitive to intake [20], [Martin et al., unpublished results], meaning that lutein concentrations in milk were strongly inversely related to milk yield. This is consistent with the fact that lutein yield did not significantly vary during the first 3 periods. It may be thought that $\beta$-carotene in milk could be more sensitive to evolutions in herbage maturity stage with a feeding management strategy allowing a better maintenance of milk yield. In contrast, the increase in milk terpenes with herbage development observed in the present study [24] may be less important with more steady milk yield. Indeed, the high increase in terpene concentration in herbage during the first 3 periods, which was due to the increase in dicotyledon proportion (17 to $31 \%$ ) and maturity stage (development of flowers and fruits of the plants), induced a high increase in terpene concentrations in milk that was exacerbated by the decrease in milk yield. This highlights the complementarity of terpenes and carotenoids as tools for tracing grazing management.

Lastly, no effect of day nested in period on milk carotenoid concentrations was observed. This may be related to the short period lengths. Almost 10 days are necessary before significant differences can be shown in milk $\beta$-carotene concentrations following changes in $\beta$-carotene intake in mid-lactation [20]. 
The B-carotene concentrations in pasture were $22 \%$ higher under SG than in $\mathrm{RG}$, but no significant effect of grazing management system was observed on Bcarotene in milk. In contrast, although lutein concentrations were similar for both $\mathrm{SG}$ and RG in pasture, they were $25 \%$ higher in milk under SG than under RG. This may be related to between-group differences in feeding choices of animals at pasture, as supported by previously reported results on terpenes [24]. Also, it cannot be ruled out that the differences in $\beta$-carotene concentrations in pasture between SG and RG, which were only slight, were not strong enough to induce shortterm differences in milk.

\section{CONCLUSIONS}

This study revealed a wide range of carotenoids in diversified mountain grassland. Although carotenoid concentrations paralleled changes in the nutritive value of grass related to maturity stage, we could only demonstrate slight changes in carotenoid concentrations during the first cycle of vegetation. This study was conducted under severe dryness conditions in this area, and thus the effects of phenological stage under more usual climatic conditions remain unclear. Carotenoid concentrations in milk varied only slightly, but could be more responsive to grass maturity stage in more intensive feeding systems. In contrast, there were no differences in carotenoid content in milk between the two grazing managements investigated in the present study. These observations should be confirmed in more usual climatic conditions.

\section{REFERENCES}

[1] Andrieu J., Demarquilly C., Wegat-Litré E., Tables de prévision de la valeur alimentaire des fourrages, in: INRA (Ed.), Prévision de la valeur nutritive des aliments des ruminants, Route de St-Cyr, Versailles, France, 1981, pp. 345-583.

[2] Ascarelli I., Edelman Z., Rosenberg M., Follman Y., Effect of dietary carotene on fertility of high-yielding dairy cows, Anim. Prod. 40 (1985) 195-207.

[3] Cardinault N., Doreau M., Nozière P., Devenir des caroténoïdes dans le rumen, Renc. Rech. Ruminants 11 (2004) 82.

[4] Cardinault N., Doreau M., Poncet C., Nozière P., Digestion and absorption of carotenoids in sheep fed fresh red clover, Anim. Sci. 82 (2005) 49-55.

[5] Chauveau-Duriot B., Thomas D., Portelli J., Doreau M., Carotenoids content in forages: variation during conservation, Renc. Rech. Ruminants 12 (2005) 117.

[6] Chew B.P., Role of Carotenoids in the immune response, J. Dairy Sci. 76 (1993) 2804-2811.

[7] Chew B.P., Hollen L.L., Hillers J.K., Herlugson M.L., Relationship between vitamin $\mathrm{A}$ and $\mathrm{B}$-carotene in blood plasma and milk and mastitis in Holsteins, J. Dairy Sci. 65 (1982) 2111-2118.

[8] Dumont B., Diet preferences of herbivores at pasture, Ann. Zootech. 46 (1997) 105-116.

[9] Faverdin Ph., Hoden A., Coulon J.B., Recommandations alimentaires pour les vaches laitières, Bull. Tech. CRZV INRATheix 70 (1987) 133-152.

[10] Ginane C., Petit M., D’Hour P., How do grazing heifers choose between maturing reproductive and tall or short vegetative swards? Appl. Anim. Behav. Sci. 83 (2003) 15-27.

[11] Havemose M.S., Weisbjerg M.R., Bredie W.L.P., Nielsen J.H., Influence of feeding different types of roughage on the oxidative stability of milk, Int. Dairy J. 14 (2004) 563-570.

[12] INRA, Recommended allowances and feed tables, in: Jarrige R. (Ed.), Ruminant Nutrition, INRA, Paris, France, 1989.

[13] Livingston A.L., Smith D., Carnahan H.L., Xnowles R.E., Nelson J.W., Kohler G.O., Variation in the xanthophylls and carotene content of Lucerne, clovers and grasses, J. Sci. Food Agr. 19 (1968) 632-636.

[14] Lyan B., Azais-Braesco V., Cardinault N., Tyssandier V., Borel P., Alexandre-Gouabau M.C., Grolier P., Simple method for clinical determination of 13 carotenoids in human plasma using an isocratic highperformance liquid chromatographic 
method, J. Chromatogr. B 751 (2001) 297-303.

[15] Martin B., Fedele V., Ferlay A., Grolier P., Rock E., Gruffat D., Chilliard Y., Effects of grass-based diets on the content of micronutrients and fatty acids in bovine and caprine dairy products, in: Lüscher A., Jeangros B., Kessler W., Huguenin O., Lobsiger M., Millar N., Suter D. (Eds.), Land Use Systems in Grassland Dominated Regions, Grass. Sci. Eur. 9 (2004) 876-886.

[16] Martin B., Cornu A., Kondjoyan N., Ferlay A., Verdier-Metz I., Pradel P., Rock E., Chilliard Y., Coulon J.B., Berdagué J.L., Milk indicators for recognizing the types of forages eaten by dairy cows, in: Hocquette J.F., Gigli S. (Eds.), Indicators of milk and beef quality, EAAP Publ. 112, Wageningen Academic Publishers, Wageningen, The Netherlands, 2005, pp. 127-136.

[17] McDowall F.H., McGillivray W.A., Studies on the properties of New Zealand butterfat VII. Effect of the stage of maturity of ryegrass fed to cows on the characteristics of butterfat and its carotene and vitamin A contents, J. Dairy Res. 30 (1963) 59-66.

[18] Michal J.J., Heirman L.R., Wong T.S., Chew B.P., Modulatory effects of dietary $\beta$ carotene on blood and mammary function in periperturient dairy cows, J. Dairy Sci. 7 (1994) 1408-1421.

[19] Minitab 13.2. Minitab Inc., Quality Plaza 1829 Pine Hall Rd State College PA 168013008, USA, 2000.

[20] Nozière P., Grolier P., Durand D., Ferlay A., Pradel P., Martin B., Variations of carotenoids, fat soluble micronutrients and color in cows' plasma and milk following changes in forage and feeding level, J. Dairy Sci. 89 (2006) 2634-2648.

[21] Prache S., Priolo A., Grolier P., Persistence of carotenoid pigments in the blood of concentrate-finished grazing sheep: its significance for the traceability of grassfeeding, J. Anim. Sci. 81 (2003) 360-367.

[22] Prache S., Priolo A., Jailler H., Dubroeucq H., Micol D., Martin B., Traceability of grass-feeding by quantifying the signature of carotenoid pigments in herbivores meat, milk and cheese, Grass. Sci. Eur. 7 (2002) 592-593.

[23] Statistical Analysis System, SAS/STAT User's Guide, SAS Institute Inc., Cary, NC, 1996.

[24] Tornambé G., Cornu A., Pradel P., Kondjoyan N., Carnat A.P., Petit M., Martin B., Changes in terpene content in milk from pasture-fed cows, J. Dairy Sci. 89 (2006) 2309-2319.

[25] Van den Berg H., Faulks R., Granado H.F., Hirschberg J., Olmedilla B., Sandmann G., Southon S., Stahl W., The potential for the improvement of carotenoid levels in foods and the likely systemic effects, J. Sci. Food Agr. 80 (2000) 880-912.

[26] Winkelman A.M., Johnson D.L., MacGibbon A.K.H., Estimation of heritabilities and correlations associated with milk color traits, J. Dairy Sci. 82 (1999) 215-224.

[27] Yang A., Larsen T.W., Tume R.K., Carotenoid and retinol concentrations in serum, adipose tissue and liver and carotenoids transport in sheep, goats and cattle, Aust. J. Agr. Res. 43 (1992) 1809-1817. 